\title{
Petrography, mineral chemistry and shock metamorphism of Yamato 984028 lherzolitic shergottite
}

\author{
HU Sen ${ }^{1,2}$, FENG Lu ${ }^{1,2} \&$ LIN YangTing ${ }^{1 *}$ \\ ${ }^{1}$ Key Laboratory of the Earth's Deep Interior, Institute of Geology and Geophysics, Chinese Academy of Sciences, Beijing 100029, China; \\ ${ }^{2}$ Graduate University of Chinese Academy of Sciences, Beijing 100049, China
}

Received January 26, 2011; accepted February 17, 2011; published online April 13, 2011

\begin{abstract}
Y984028 is a new lherzolitic shergottite, consisting of poikilitic and non-poikilitic lithologies. The mafic silicates are FeO-poor, and the chromite is $\mathrm{TiO}_{2}$-poor in the poikilitic lithology compared to the grains in the non-poikilitic lithology. This meteorite shares similar mineral petrography and mineral chemistry with GRV 99027, but is not paired with the latter because of their different shock-induced features. Y984028 was severely shocked and experienced no significant thermal metamorphism after the main impact event. Hence, Y984028 serves as a probe for the study of meteorite impact processes on terrestrial surfaces. The melt veins in Y984028 are characterized by the absence of any high-pressure polymorphs, the presence of abundant small mineral fragments, and the prevailing granulation textures of olivine and chromite. These features are consistent with adiabatic melting during the release of shock-induced high-pressure and quenching at ambient pressure.
\end{abstract}

Mars, shergottite, lherzolite, Antarctica, shock metamorphism

Citation: $\quad$ Hu S, Feng L, Lin Y T. Petrography, mineral chemistry and shock metamorphism of Yamato 984028 lherzolitic shergottite. Chinese Sci Bull, 2011, 56: 1579-1587, doi: 10.1007/s11434-011-4443-x

Lherzolitic shergottites belong to a small subgroup of Martian meteorites. Twelve of these meteorites have been reported to date. All of them have two textural lithologies-poikilitic and non-poikilitic. The poikilitic lithology consists of pyroxene oikocrysts and olivine chadacrysts with minor inclusions of chromite. The non-poikilitic lithology contains euhedral to subeuhedral olivine, augite and pigeonite, with interstitial plagioclase glass and minor chromite, ilmenite, pyrrhotite and phosphates. In addition, the mineral chemistry of lherzolitic shergottites shows bimodal patterns, with higher Fa contents of olivine, Fs contents of pyroxene and $\mathrm{Ti}$ contents of chromite in the non-poikilitic lithology.

An intensive study of the first three lherzolitic shergottites (i.e. Allan Hill [ALH] A77005, Yamato [Y-] 793605 and Lewis Cliff [LEW] 88516) revealed similarities in petrography and mineral chemistry [1-6], Sm-Nd and Rb-Sr

*Corresponding author (email: linyt@ mail.igcas.ac.cn) isochron ages [7,8] and ejection events [9-11] among them. Thus, lherzolitic shergottites could have been ejected from the same igneous unit on Mars by a single impact event. The similarities among lherzolitic shergottites were confirmed by the discovery of new meteorites of this group, including GRV 99027 [12-15], Yamato (Y) 000027 (paired with Y000047 and Y000097) [16] and Northwest Africa (NWA) 1950 [17]. Only two lherzolitic shergottites (i.e. GRV 020090 [14,18] and Roberts Massif [RBT] 04261 (aired with RBT 04262)[19,20]), are significantly evolved with high abundances of rare Earth elements (REEs) and other incompatible elements. Study of new samples is clearly important for identifying the petrogenesis of lherzolitic shergottites.

\section{Sample and experiments}

Y984028 is a new member of the lherzolitic shergottites 
(Meteorite Newsletter 17, 2008). A consortium on this meteorite was organized by Dr. Misawa, National Institute of Polar Research (NIPR), Japan. As a part of this consortium, we studied the petrography and mineral chemistry of Y984028, and compared them with those of GRV 99027 and other lherzolitic shergottites. The preliminary results have been reported [21].

The sample studied in this work is a polished thin section of Y984028, numbered as Y984028, 51-2. It contains blackcolored, shock-induced melt veins and a fusion crust on one side of the rectangular section. The sample was observed under an optical microscope and a Scanning Electron Microscope LEO 1450VP equipped with an energy dispersive spectrometer, at the Institute of Geology and Geophysics, Chinese Academy of Sciences (IGGCAS). Raman spectra were collected using an in-via reflex Renishaw at the Technical Institute of Physics and Chemistry, Chinese Academy of Sciences. The laser had a wavelength of $532 \mathrm{~nm}$, and was focused on the surface of spot samples with a diameter of 1 $\mu \mathrm{m}$ and at $20 \%$ of $80 \mathrm{~mW}$ laser power. Quantitative analyses of minerals were conducted with an electron probe microanalyzer (EPMA) JEOL-8100 at IGGCAS. The accelerating voltage was $15 \mathrm{kV}$, and the beam current was $20 \mathrm{nA}$, with the exception of $10 \mathrm{nA}$ for plagioclase. The EPMA standards were natural and synthetic minerals: natural kaersutite for $\mathrm{Si}, \mathrm{Mg}$ and $\mathrm{Fe}$, jadeite for $\mathrm{Na}$ and $\mathrm{Al}$, bustamite for $\mathrm{Ca}$ and $\mathrm{Mn}$, and $\mathrm{K}$-feldspar for $\mathrm{K}$, synthetic rutile for $\mathrm{Ti}$ and $\mathrm{Cr}_{2} \mathrm{O}_{3}$ for $\mathrm{Cr}$. X-ray interference of the $\mathrm{K}_{a}$ line of $\mathrm{Mn}$ by the $\mathrm{K}_{\beta}$ line of $\mathrm{Cr}$ was corrected. A Bence-Albee procedure was used for data reduction. The detection limits were: $0.01 \mathrm{wt} \%$ for $\mathrm{K}_{2} \mathrm{O}, 0.02 \mathrm{wt} \%$ for $\mathrm{SiO}_{2}, \mathrm{Al}_{2} \mathrm{O}_{3}, \mathrm{~V}_{2} \mathrm{O}_{3}, \mathrm{MgO}$, $\mathrm{CaO}, \mathrm{Na}_{2} \mathrm{O}$ and $\mathrm{P}_{2} \mathrm{O}_{5}, 0.03$ wt\% for $\mathrm{TiO}_{2}$ and $\mathrm{Cr}_{2} \mathrm{O}_{3}, 0.05$ $\mathrm{wt} \%$ for $\mathrm{FeO}$, and $0.06 \mathrm{wt} \%$ for $\mathrm{NiO}$ and $\mathrm{MnO}$. Modal compositions of the individual textural lithologies for the entire section were calculated from the surface areas of minerals on a photo mosaic of the back-scattered electron
(BSE) images, and normalized to 100 vol\%.

\section{Results}

\subsection{Petrography}

Y984028 has two textural lithologies (Figure 1). These lithologies are poikilitic and non-poikilitic, which are typical of lherzolitic shergottites. In the poikilitic lithology, rounded olivine chadacrysts (50-1200 $\mu \mathrm{m}, 39.6 \mathrm{vol} \%)$ and euhedral chromite (30-100 $\mu \mathrm{m}, 1.1 \mathrm{vol} \%)$ were included in low-Ca pyroxene oikocrysts (58.3 vol\%). Minor Capyroxene was found at the rims of the pyroxene oikocrysts. In the non-poikilitic lithology, there was abundant plagioclase glass $(15.1 \mathrm{vol} \%)$ interstitial to euhedral or subeuhedral olivine $(68.2 \mathrm{vol} \%)$ and pyroxenes $(15.2 \mathrm{vol} \%)$. The abundance ratio of olivine to pyroxenes was significantly higher (4.5) in the non-poikilitic lithology than in the poikilitic (0.7). Ti-rich chromite $(1.1 \mathrm{vol} \%)$ and pyrrhotite $(0.4 \mathrm{vol} \%)$ were confined to the non-poikilitic lithology, and usually occurred at the boundaries of plagioclase glass. In both textural lithologies, olivine appeared brownish under planepolarized light, and pyroxenes had no exsolution. All grains of plagioclase have been transformed to amorphous interiors, as noted under cross-polarized light and confirmed by Raman spectra. The modal compositions of Y984028 are summarized in Table 1.

In the high contrast mode of the back-scattered electron (BSE) images, grains of plagioclase glass usually show brightness to various degrees compared to one another (Figure 2(a) and (b)). The relatively darker grains usually occur as rims or are interstitial to the brighter ones. Fine-grained assemblages of pyroxene, merrilite, ilmenite and accessory baddeleyite, probably crystallized from the last residual liquid, were found within plagioclase (Figure 2(c)). A few

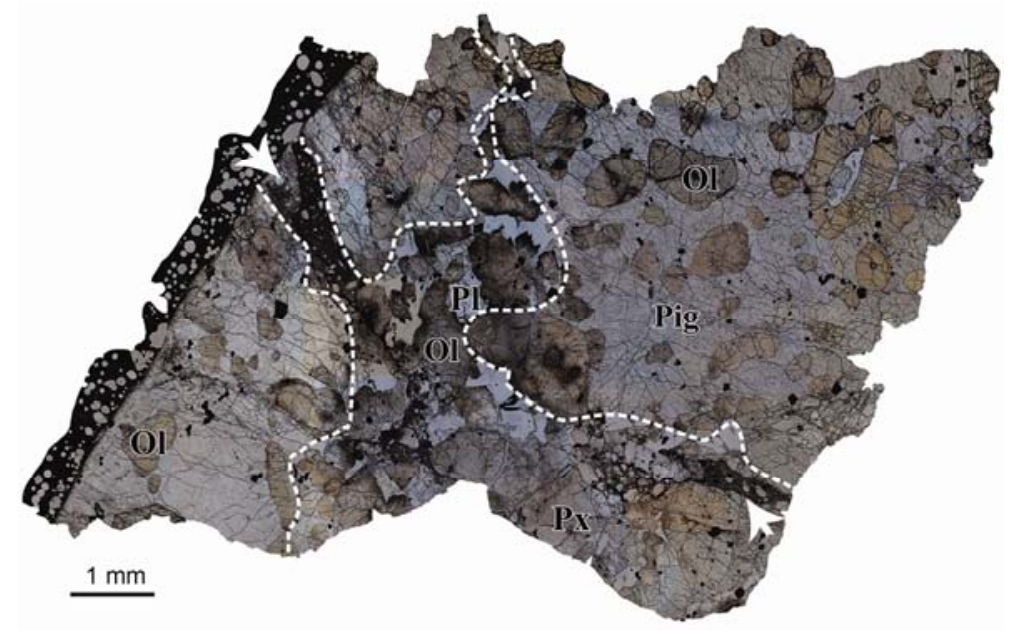

Figure 1 Photo mosaic of Y984028 under plane-polarized light. The middle area is the non-poikilitic lithology (outlined with dashed lines), consisting mainly of olivine $(\mathrm{Ol})$, pyroxene (Px) and interstitial plagioclase glass $(\mathrm{Pl})$. The left and right sides are poikilitic lithologies, consisting predominantly of round olivine chadacrysts in pigeonite oikocrysts (Pig). Small black grains enclosed in olivine and pyroxenes are chromite. Note the shock-induced melt vein (arrows) across the section and the fusion crust at the edge on the left. Olivine is typically brownish in color. 
Table 1 Modal compositions of Y984028 compared with other lherzolitic shergottites (vol\%)

\begin{tabular}{|c|c|c|c|c|c|c|c|c|c|c|c|c|c|}
\hline \multirow[b]{3}{*}{ Olivine } & \multicolumn{3}{|c|}{ Y984028 } & \multicolumn{3}{|c|}{ GRV 99027} & \multirow{2}{*}{\multicolumn{2}{|c|}{$\begin{array}{c}\text { ALHA77005 } \\
\text { bulk }\end{array}$}} & \multirow{2}{*}{\multicolumn{3}{|c|}{$\frac{\text { LEW } 88516}{\text { bulk }}$}} & \multirow{2}{*}{\multicolumn{2}{|c|}{$\begin{array}{c}\text { Y793605 } \\
\text { bulk } \\
\end{array}$}} \\
\hline & \multirow{2}{*}{$\begin{array}{c}\text { poikilitic } \\
39.6\end{array}$} & \multirow{2}{*}{$\begin{array}{c}\text { non-poikilitic } \\
688.2\end{array}$} & \multirow{2}{*}{$\frac{\text { bulk }}{48.2}$} & \multirow{2}{*}{$\begin{array}{c}\text { poikilitic } \\
30.9\end{array}$} & \multirow{2}{*}{$\begin{array}{c}\text { non-poikilitic } \\
33.9\end{array}$} & \multirow{2}{*}{$\begin{array}{l}\text { bulk } \\
32.1\end{array}$} & & & & & & & \\
\hline & & & & & & & 59.5 & 69.3 & 49.6 & 59 & 57 & 40.4 & 40 \\
\hline Plagioclase glass & 1.0 & 15.1 & 5.3 & & 14.6 & 5.8 & 15.4 & 13.4 & 9.3 & 12 & 16 & 7.4 & 8 \\
\hline Chromite+ilmenite & 1.1 & 1.5 & 1.2 & 1.2 & 0.9 & 1.1 & 0.7 & 2.1 & 0.8 & 0.9 & 3 & 1.4 & 1.5 \\
\hline Phosphates & & & & & 1.4 & 0.5 & 1.7 & 0.5 & 1.0 & 1.7 & $<1$ & & \\
\hline Reference & & this work & & [13] & [13] & {$[13]$} & {$[22]$} & [4] & [4] & {$[22]$} & {$[4]$} & [3] & [6] \\
\hline
\end{tabular}
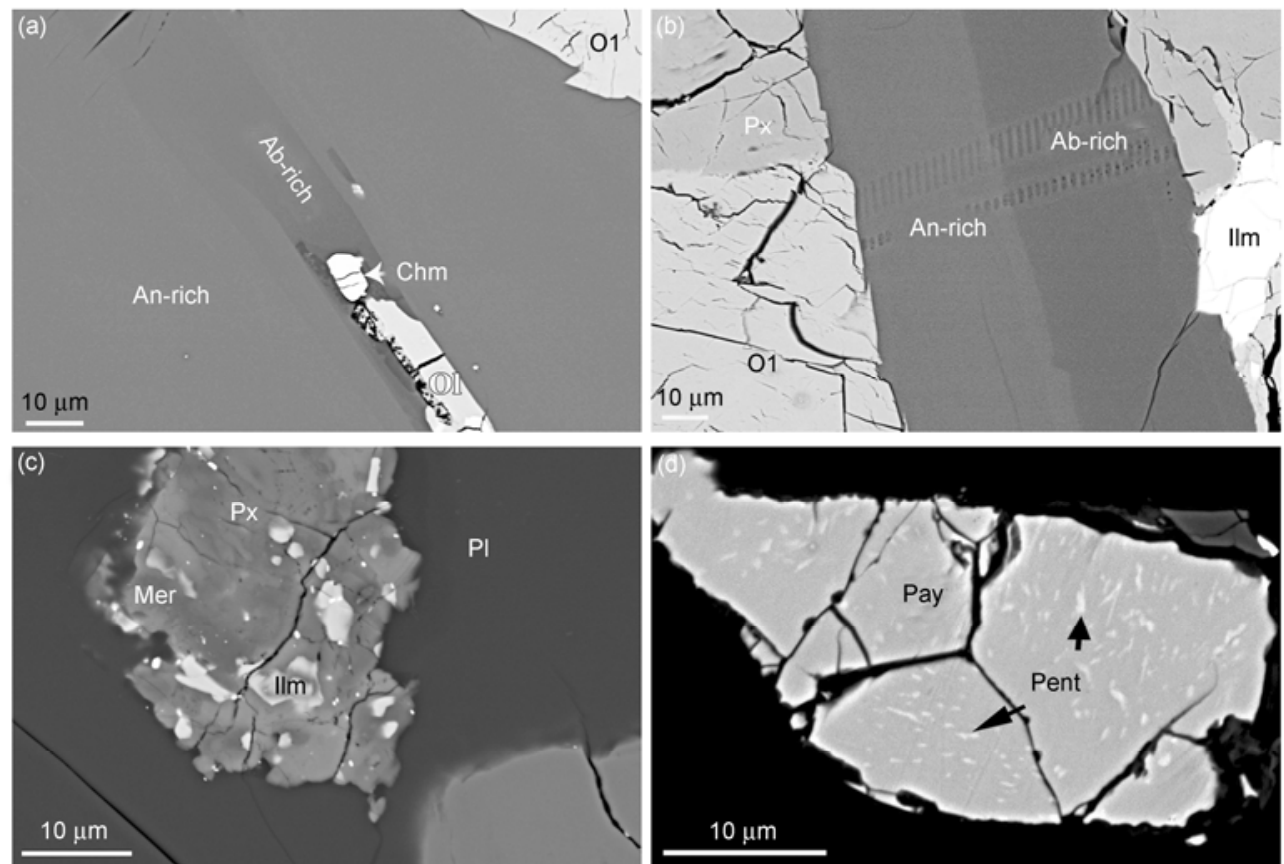

Figure 2 BSE images of Y984028. (a) Assemblage of Ab-rich plagioclase (Ab-rich), chromite (Chm) and olivine (Ol) embedded in An-rich plagioclase (An-rich). (b) Coexistence of Ab-rich and An-rich plagioclase grains. The dark dots are due to the EPMA analysis. (c) Mineral assemblage within plagioclase, consisting of pyroxene (Px), merrilite (Mer), ilmenite (Ilm) and accessory baddeleyite (bright spots). (d) Pyrrhotite (Pyr), containing small grains and needles that are probably pentlandite (Pent), inferred from the high Ni content.

baddeleyite $(<5 \mu \mathrm{m})$ grains were found in association with ilmenite. Small grains and needles as exsolutions in pyrrhotite (Pyr) were probably pentlandite inferred from the high Ni content (Figure 2(d)).

Magmatic inclusions are abundant in olivine, with round or ovoid shapes and up to $120 \mu \mathrm{m}$ in diameter. In contrast, very few magmatic inclusions were found in pyroxene oikocrysts and chromite (Figure 3). In the magmatic inclusions in olivine, Ca-pyroxene crystallized from the wall inwards, and the cores of the inclusions usually consisted of euhedral grains of Ca-pyroxene, silica glass and K-rich feldspar embedded in feldspathic glass. Some magmatic inclusions in olivine showed very complicated mineral assemblages, while the others consisted predominantly of low-Ca pyroxene or feldspar glass. Comparatively, the magmatic inclusions in chromite were very small in size $(<5$ $\mu \mathrm{m}$, Figure 3(d)) and consisted of feldspathic compositions according to the EPMA analyses. No high-pressure poly- morphs were identified within these inclusions using Raman spectroscopy.

\subsection{Shock-induced effects}

Y984028 shows severe shock metamorphism. All the plagioclase crystals have been transformed to glass. Olivine and pyroxene commonly show mosaic extinction under cross-polarized light. A remarkable feature of Y984028 is the unique microtextures of the melt veins (Figure 4). The matrix of the veins consists mainly of glass and small irregular fragments of minerals, without high-pressure polymorphs of olivine, pyroxene or plagioclase (Figure 4(a) and (b)). This was distinct from common occurrences of finegrained majorite-pyrope and ringwoodite matrix of impact melt veins in heavily shocked ordinary chondrites [23]. In addition, silicate glass in the melt veins occurred as curved and elongated bands, which are indicative of flow textures 
(Figure 4(a) and (b)). These observations are consistent with melting at ambient pressure after decompression. Almost all clasts of the host rock entrained in the veins and many minerals in contact with the veins have been completely granulated, and the outlines of some granulated clasts are unclear (Figure 4(b) and (c)). The small grains at the margins of a few granulated clasts showed re-crystallization, and they usually were concentrically zoned (Figure 4(d)). In addition, chromite was commonly mixed with the granulated olivine and pyroxene as a thin network along grain boundaries (Figure 4(b)).

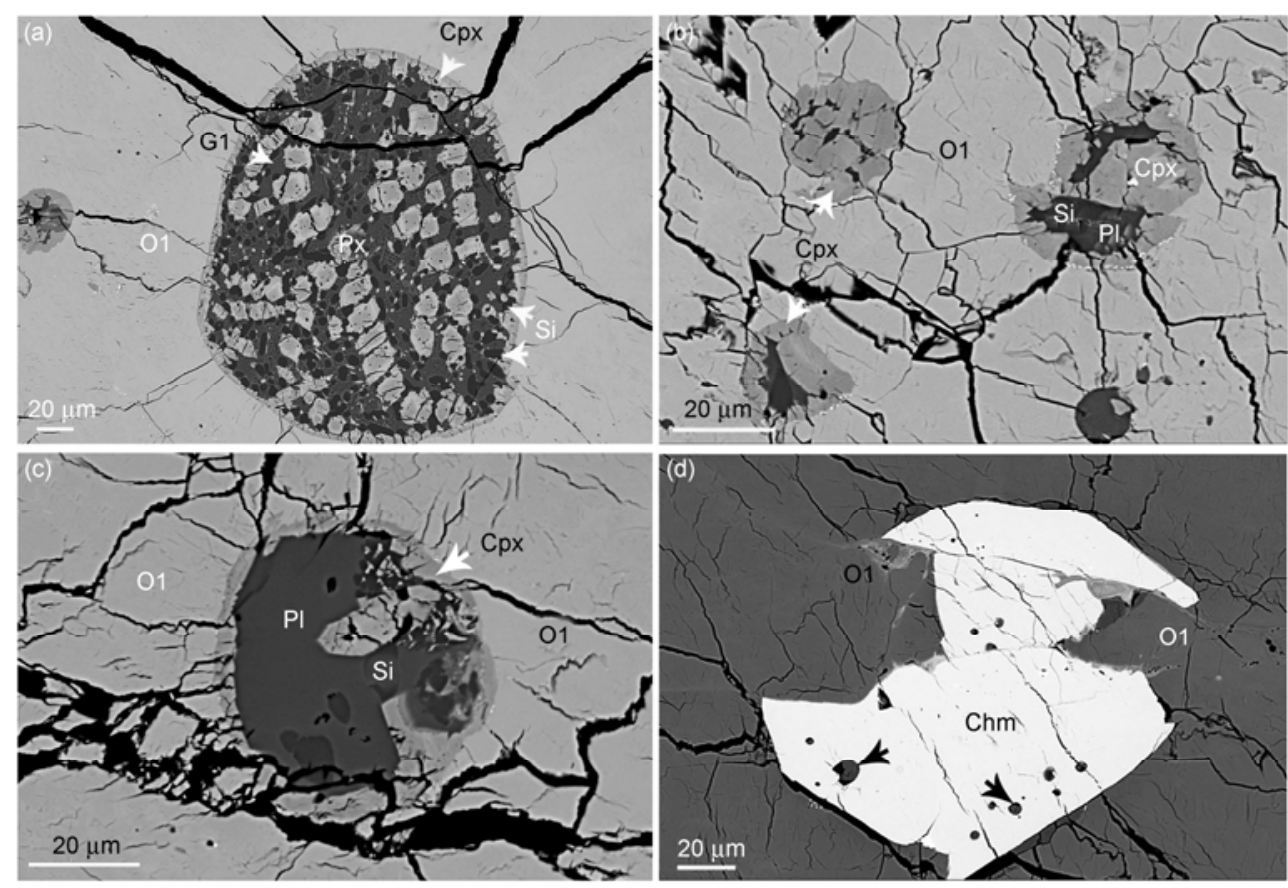

Figure 3 BSE images of magmatic inclusions in Y984028. (a) A large magmatic inclusion in olivine, consisting of Ca-pyroxene (Cpx), silica glass ( $\mathrm{Si})$ and feldspathic glass (Gl). (b) Several magmatic inclusions in olivine, consisting of Ca-pyroxene, silica glass (Si) and feldspathic glass (Gl). (c) Another magmatic inclusion in olivine with Ca-pyroxene rim. Silica glasses are enclosed in plagioclase. (d) Small and dark magmatic inclusions (arrows) in chromite.
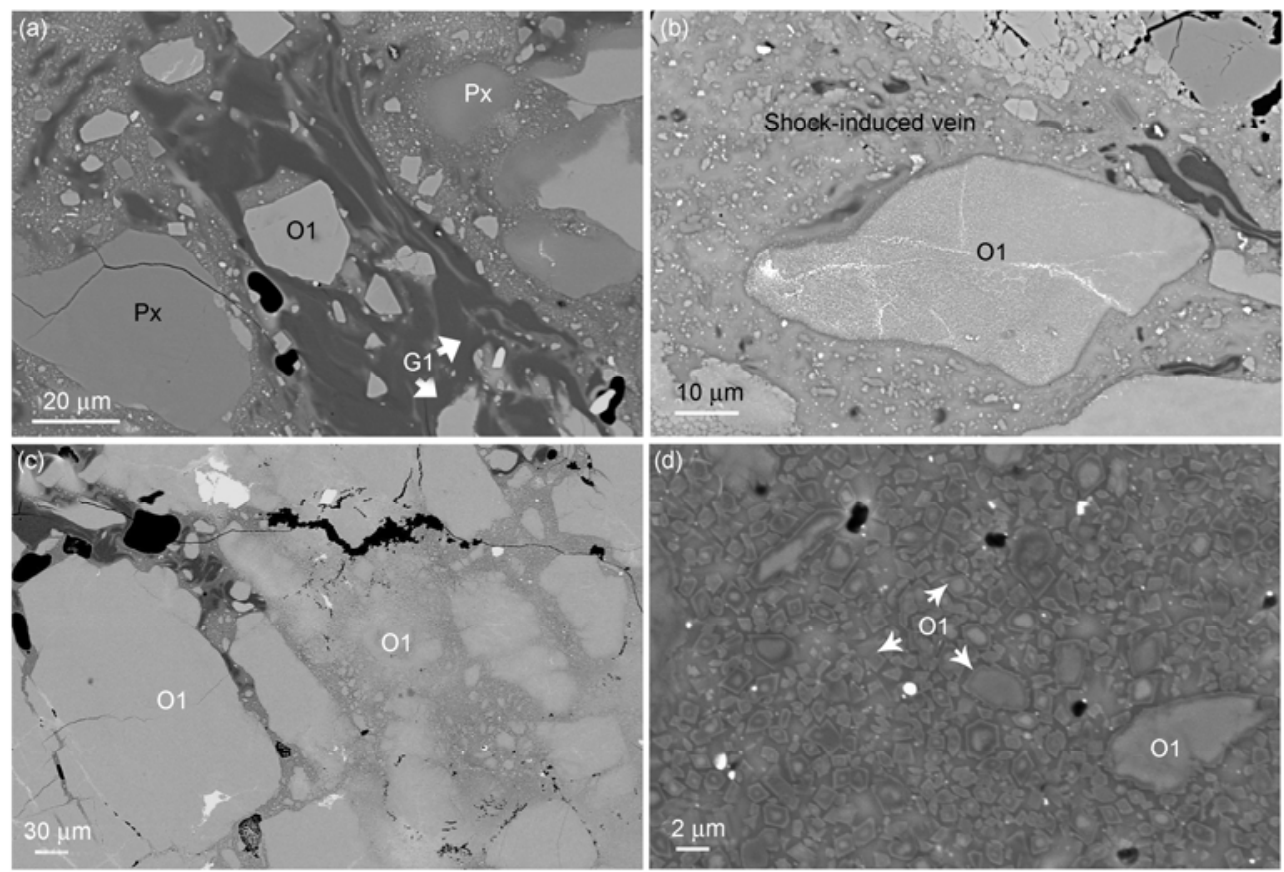

Figure 4 Melt veins of Y984028. (a) Olivine (Ol) and pyroxene (Px) clasts entrained in the melt vein. Note the flow features of the melt, consisting mainly of feldspathic glass (Gl) with thin schlieren of olivine and pyroxene melts (light grey). (b) An olivine clast in the melt vein showing fragmentation and incipient post-shock melting. (c) Outlines of granulated olivine clasts became unclear during partial post-shock melting. (d) Concentric zoning of small olivine grains at the margin of a granulated olivine clast entrained in the melt vein. 
In addition to the large melt vein described above, there were shock-induced melt veinlets (10-30 $\mu \mathrm{m}$ in width). These veinlets showed distinct textures (Figure 5). Pyroxene was partially melted, and then quenched to form dendritic crystals (Figure 5(a)). Olivine also was partially melted, but showed no typical dendritic texture as did pyroxene. Conversely, olivine along the veinlets exhibited lamellae with two directions (Figure 5).

Raman analysis of the fine-grained matrix and the granulated mineral fragments entrained in the melt veins showed no signatures of majorite, ringwoodite or other high-pressure polymorphs. The lamellae in olivine in contact with the melt veinlets showed typical Raman spectra of olivine, while the smooth zone of pyroxene in contact with the veinlets has been transformed to glass.

\subsection{Mineral chemistry}

Olivine: It shows a bimodal pattern of the fayalite (Fa) content associated with the occurrences of the analyzed grains in the poikilitic and non-poikilitic lithologies (Figure 6). The olivine chadacrysts in the poikilitic lithology had lower Fa contents (average of $27.8 \pm 1.5 \mathrm{~mol} \%$, with a range of $25.5 \mathrm{~mol} \%-30.8 \mathrm{~mol} \%$ ) than in the non-poikilitic lithology (average of $31.4 \pm 0.9 \mathrm{~mol} \%$, with a range of $29.6 \mathrm{~mol} \%-$ $33.5 \mathrm{~mol} \%$ ). However, individual grains of olivine in both textural lithologies were rather homogeneous. The other minor elements were $\mathrm{MnO}(0.54 \pm 0.05 \mathrm{wt} \%)$ and $\mathrm{CaO}$ $(0.18 \pm 0.06 \mathrm{wt} \%)$, with a $\mathrm{FeO} / \mathrm{MnO}$ ratio of $49.1 \pm 3.2$. The representative analyses are given in Table 2.

Low-Ca pyroxene: The chemical compositions of low-Ca pyroxene also were correlated with occurrences (Figures 7 and 8 ). The pyroxene oikocrysts contained distinguishably lower $\mathrm{FeO}$ amounts $\left(\mathrm{Fs}_{21.4-23.9}\right)$ than the grains in the non-poikilitic lithology $\left(\mathrm{Fs}_{24.6-29.8}\right)$ (Figure 7). $\mathrm{Al}_{2} \mathrm{O}_{3}, \mathrm{TiO}_{2}$ and $\mathrm{CaO}$ contents also were lower in the pyroxene oikocrysts $(0.64 \pm 0.36 \mathrm{wt} \%, 0.17 \pm 0.13 \mathrm{wt} \%$ and $3.15 \pm 0.98$ $\mathrm{wt} \%$, respectively) than in the non-poikilitic lithology $(0.83 \pm 0.35 \mathrm{wt} \%, 0.54 \pm 0.29 \mathrm{wt} \%$ and $4.41 \pm 0.82 \mathrm{wt} \%$, respectively). Conversely, $\mathrm{Cr}_{2} \mathrm{O}_{3}$ showed no difference in both occurrences $(0.12 \mathrm{wt} \%-1.01 \mathrm{wt} \%)$. It is noted that $\mathrm{Al}_{2} \mathrm{O}_{3}$ shows a correlation with both $\mathrm{CaO}$ and $\mathrm{TiO}_{2}$ in the low-Ca pyroxene oikocrysts, but this trend did not appear in the analyses of grains in the non-poikilitic lithology (Figure 8). Individual crystals of the low-Ca pyroxene were relatively homogeneous regardless of the size and shape variation among them. Their $\mathrm{FeO} / \mathrm{MnO}$ ratio was $27.8 \pm 2.3$. Representative analyses of low-Ca pyroxene are given in Table 2.
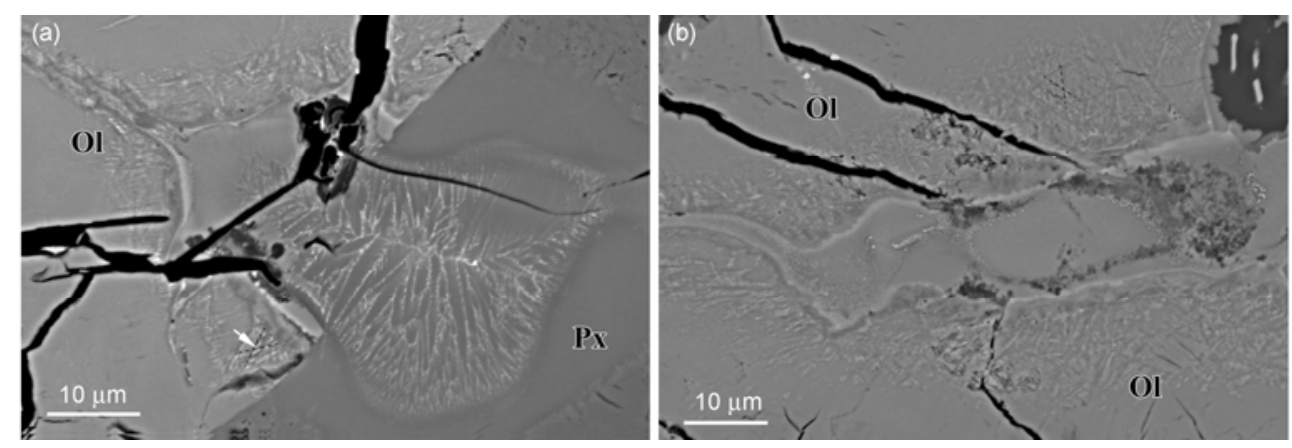

Figure 5 Melt veinlets of Y984028. (a) Localized veinlets show dendritic crystals of pyroxene surrounded by a zone of pyroxene glass (Px) with a smooth surface. Olivine $(\mathrm{Ol})$ also is partially melted (smooth on the surface) where in contact with the pyroxene melt. Note two-directional lamellae (black dotted lines) between the olivine host and melt. (b) Another veinlet in olivine (Ol) that shows two-directional lamellae (black dotted lines) surrounding the melt with a smooth surface.

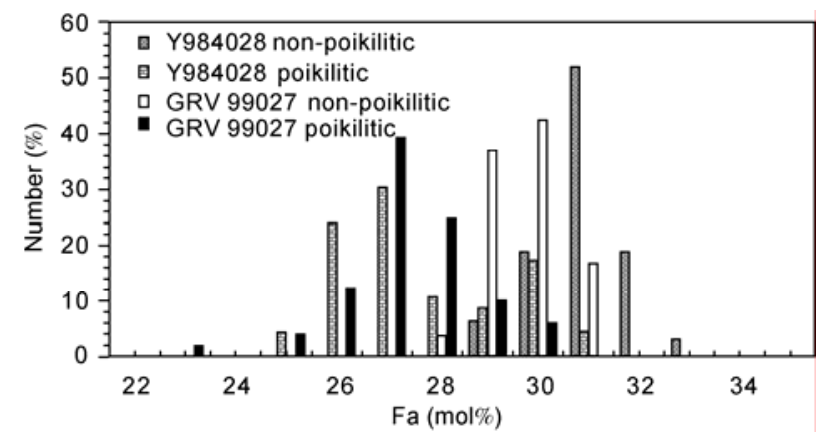

Figure 6 The Fa content distribution of olivine in Y984028, compared to GRV 99027. The olivine chadacrysts in the poikilitic lithology have lower Fa than the grains in the non-poikilitic lithology, both overlapping with their counterparts in GRV 99027 [13], respectively.
Augite: In the poikilitic lithology, it occurs only as rims of the low-Ca pyroxene oikocrysts. The compositions of augite varied from $\mathrm{En}_{42.6} \mathrm{Fs}_{13.1} \mathrm{Wo}_{44.2}$ to $\mathrm{En}_{55.9} \mathrm{Fs}_{23.0} \mathrm{Wo}_{21.1}$, but there were no significant compositional differences between the two textural lithologies (Figure 7). Minor elements were $\mathrm{Al}_{2} \mathrm{O}_{3}(0.71 \mathrm{wt} \%-5.73 \mathrm{wt} \%), \mathrm{TiO}_{2}(0.30 \mathrm{wt} \%-$ $1.90 \mathrm{wt} \%), \mathrm{Cr}_{2} \mathrm{O}_{3}(0.09 \mathrm{wt} \%-0.95 \mathrm{wt} \%)$ and $\mathrm{MnO}(0.27$ wt $\%-0.56$ wt $\%$ ), with $\mathrm{Al}_{2} \mathrm{O}_{3}$ and $\mathrm{Cr}_{2} \mathrm{O}_{3}$ positively correlated with $\mathrm{CaO}$ (10.11 wt\%-19.64 wt\%). The $\mathrm{FeO} / \mathrm{MnO}$ ratio was $25.2 \pm 2.4$. The representative analyses of augite are given in Table 2 .

Feldspars: As described above, individual grains of plagioclase (all have been transformed to glass) can be recognized by their different brightness in high-contrast BSE images (i.e. 
Table 2 Representative analyses of major and minor minerals chemistry (wt\%)

\begin{tabular}{|c|c|c|c|c|c|c|c|c|c|c|c|c|c|c|c|c|c|c|c|c|}
\hline & \multicolumn{10}{|c|}{ Non-poikilitic } & \multicolumn{6}{|c|}{ Poikilitic } & \multicolumn{4}{|c|}{ Magmatic inclusion } \\
\hline & $\mathrm{Chm}^{\mathrm{a})}$ & $\mathrm{Ilm}^{\mathrm{b})}$ & $\mathrm{Ol}^{\mathrm{b})}$ & $\mathrm{Ol}^{\mathrm{a})}$ & $\mathrm{Pig}^{\mathrm{b})}$ & $\mathrm{Pig}^{\mathrm{a})}$ & $\mathrm{Aug}^{\mathrm{a})}$ & Aug $^{\text {a) }}$ & $\mathrm{Pl}^{\mathrm{a})}$ & $\mathrm{Pl}^{\mathrm{a})}$ & $\mathrm{Chm}^{\mathrm{a})}$ & $\mathrm{Ol}^{\mathrm{a})}$ & $\mathrm{Ol}^{\mathrm{b})}$ & $\mathrm{Pig}^{\mathrm{a})}$ & $\mathrm{Pig}^{\mathrm{b})}$ & $\mathrm{Aug}^{\mathrm{b})}$ & $\mathrm{Aug}^{\mathrm{a})}$ & Aug $^{\text {b) }}$ & $\mathrm{Gl}^{\mathrm{a}}$ & $\mathrm{Si}^{\mathrm{a})}$ \\
\hline $\mathrm{SiO}_{2}$ & n.d. & n.d. & 37.5 & 37.3 & 52.4 & 53.6 & 52.4 & 52.4 & 55.6 & 60.2 & 0.08 & 38.8 & 38.6 & 55.5 & 55.0 & 52.3 & 49.1 & 46.2 & 69.9 & 92.9 \\
\hline $\mathrm{TiO}_{2}$ & 15.8 & 52.9 & n.d. & n.d. & 0.62 & 0.48 & 1.30 & 0.98 & 0.12 & 0.15 & 1.26 & n.d. & 0.06 & 0.14 & 0.16 & 0.45 & 1.68 & 3.49 & 0.46 & 0.32 \\
\hline $\mathrm{Al}_{2} \mathrm{O}_{3}$ & 5.65 & n.d. & n.d. & n.d. & 1.71 & 0.98 & 1.61 & 1.13 & 27.5 & 24.6 & 7.36 & n.d. & n.d. & 0.55 & 0.59 & 2.14 & 5.28 & 10.8 & 20.2 & 4.08 \\
\hline $\mathrm{Cr}_{2} \mathrm{O}_{3}$ & 26.3 & 1.15 & n.d. & n.d. & 0.75 & 0.38 & 0.78 & 0.42 & n.d. & n.d. & 55.7 & n.d. & 0.07 & 0.46 & 0.40 & 0.75 & 0.29 & n.d. & n.d. & n.d. \\
\hline $\mathrm{FeO}$ & 46.0 & 39.1 & 27.6 & 28.1 & 16.4 & 16.5 & 10.0 & 14.1 & 0.45 & 0.39 & 28.4 & 22.4 & 23.0 & 14.5 & 14.3 & 8.89 & 7.68 & 12.8 & 1.51 & 0.25 \\
\hline $\mathrm{MnO}$ & 0.72 & 0.78 & 0.54 & 0.58 & 0.57 & 0.62 & 0.44 & 0.54 & n.d. & n.d. & 0.62 & 0.47 & 0.41 & 0.48 & 0.54 & 0.41 & 0.21 & 0.32 & 0.10 & n.d. \\
\hline $\mathrm{MgO}$ & 3.64 & 4.96 & 34.1 & 34.0 & 21.9 & 22.3 & 16.6 & 19.2 & 0.14 & n.d. & 5.00 & 36.0 & 37.4 & 26.2 & 24.4 & 16.5 & 11.6 & 5.74 & 0.46 & 0.06 \\
\hline $\mathrm{CaO}$ & n.d. & n.d. & 0.12 & 0.16 & 4.77 & 4.79 & 16.4 & 10.1 & 10.4 & 5.88 & 0.05 & 0.15 & 0.16 & 2.71 & 4.65 & 17.1 & 22.0 & 21.0 & 3.83 & 0.79 \\
\hline $\mathrm{Na}_{2} \mathrm{O}$ & n.d. & n.d. & n.d. & n.d. & 0.15 & 0.11 & 0.34 & 0.19 & 5.15 & 7.09 & n.d. & n.d. & n.d. & 0.05 & 0.07 & 0.26 & 0.30 & 0.31 & 3.46 & 0.81 \\
\hline $\mathrm{K}_{2} \mathrm{O}$ & n.d. & n.d. & n.d. & n.d. & n.d. & n.d. & n.d. & n.d. & 0.42 & 1.25 & n.d. & n.d. & n.d. & n.d. & n.d. & n.d. & n.d. & n.d. & 0.21 & 0.05 \\
\hline Total & 98.1 & 99.0 & 100.0 & 100.2 & 99.3 & 99.7 & 99.8 & 99.0 & 99.8 & 99.7 & 98.6 & 98.0 & 99.8 & 100.7 & 100.2 & 98.9 & 98.2 & 100.8 & 100.1 & 99.2 \\
\hline $\mathrm{Fa} / \mathrm{Fs} / \mathrm{An}$ & & & 31.2 & 31.7 & 26.7 & 26.5 & 16.5 & 23.0 & 51.4 & 29.1 & & 25.8 & 25.6 & 22.4 & 22.5 & 14.7 & 13.6 & 25.6 & & \\
\hline /Wo/Or & & & & & 9.9 & 9.9 & 34.7 & 21.1 & 2.5 & 7.4 & & & & 5.4 & 9.3 & 36.4 & 49.8 & 53.9 & & \\
\hline
\end{tabular}

a) Core; b) Rim; n.d.: below the detection limit. Chm, Chromite; Ilm, ilmenite; Ol, olivine; Pig, pigeonite; Aug, augite; Pl, plagioclase; Si, silica; Gl, feldspathic glass.

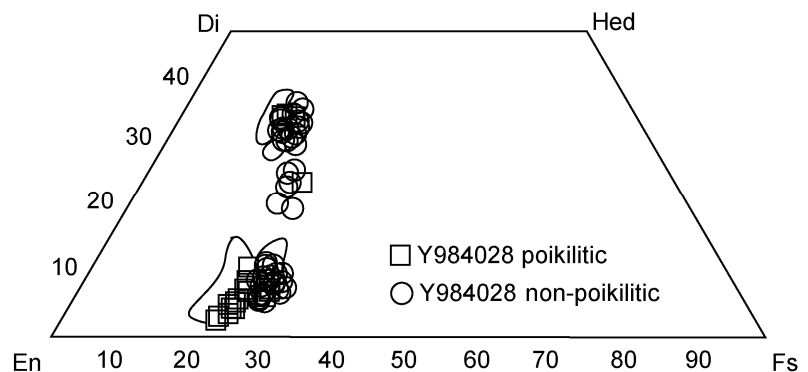

Figure 7 Pyroxene Quadrilateral (En-Fs-Hed-Di) diagram of Y984028, compared with GRV 99027 (outlined, [13]). Low-Ca pyroxene oikocrysts are Fs-poor relative to the grains in the non-poikilitic lithology. Augite in both textural lithologies has nearly the same composition.
Figure 2(a) and (b)). Quantitative analyses of the plagioclase grains with various brightness revealed correlations with chemical compositions (i.e. the brighter grains contain higher $\mathrm{CaO}$, but lower $\mathrm{K}_{2} \mathrm{O}$ than the darker ones (Figure 9)). EPMA profiles conducted on the coexisting bright and dark grains of plagioclase showed no significant compositional zoning for $\mathrm{CaO}$ and $\mathrm{K}_{2} \mathrm{O}$. Minor elements were $\mathrm{FeO}(0.17$ $\mathrm{wt} \%-0.70 \mathrm{wt} \%$, most $<0.6 \mathrm{wt} \%), \mathrm{TiO}_{2}(<0.26 \mathrm{wt} \%)$ and $\mathrm{MgO}(<0.32 \mathrm{wt} \%)$. K-rich feldspar $\left(\mathrm{An}_{12.5} \mathrm{Ab}_{46.6} \mathrm{Or}_{40.8}\right)$ was found only in the magmatic inclusions of olivine. The representative analyses are listed in Table 2.

Chromite: It shows distinct compositional trends related to the occurrences of the analyzed grains in the non-poikilitic
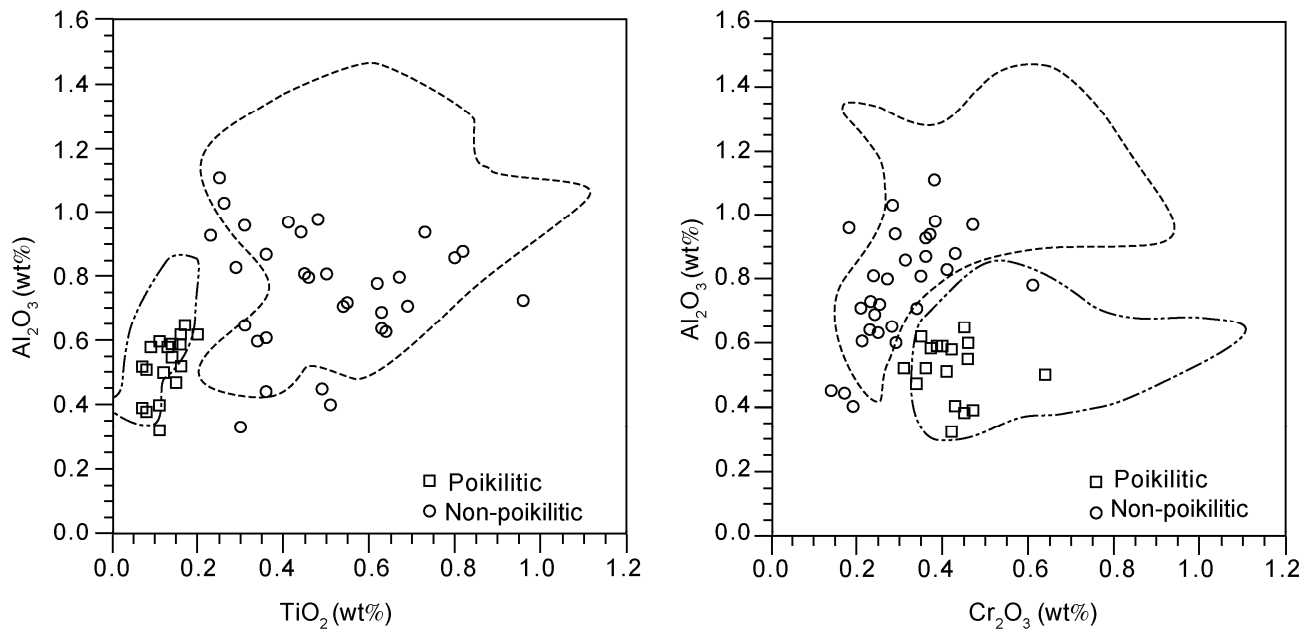

Figure 8 Compositions of low-Ca pyroxene of Y984028, compared with GRV 99027. (a) $\mathrm{Al}_{2} \mathrm{O}_{3}-\mathrm{TiO}_{2}$ plot shows a positive correlation and lowest TiO ${ }_{2}$ in the oikocrystic pyroxenes, distinct from those grains in the non-poikilitic lithology. (b) $\mathrm{Al}_{2} \mathrm{O}_{3}-\mathrm{TiO}_{2}$ plot also shows different compositional characteristics between the two occurrences. Ranges of GRV 99027 after [13]. 


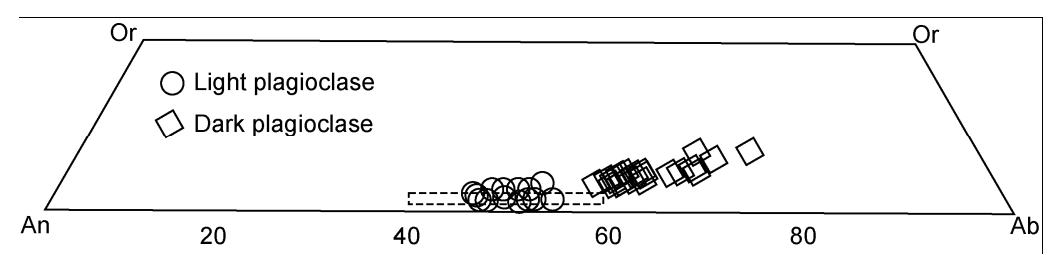

Figure 9 Compositions of plagioclase glass in Y984028, compared with GRV 99027 (dashed lines, [13]).

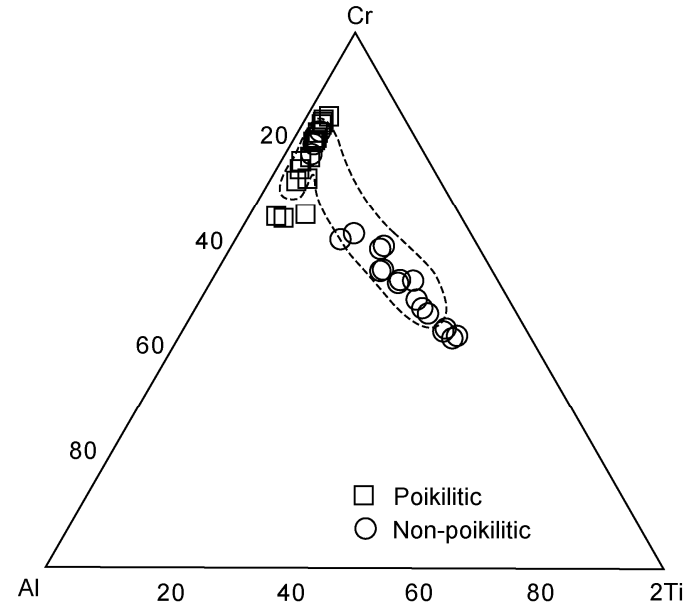

Figure 10 Atomic ratios of chromite in Y984028. The grains in the poikilitic lithology are $\mathrm{TiO}_{2}$-poor, while those in the non-poikilitic lithology are $\mathrm{TiO}_{2}$-rich, both overlapping with those of GRV99027 (dashed lines, [13]).

lithology (Figure 10). The grains included in olivine and pyroxene in the poikilitic lithology were characterized by low $\mathrm{TiO}_{2}(1.12 \mathrm{wt} \%-1.93 \mathrm{wt} \%)$, and their $\mathrm{Cr}_{2} \mathrm{O}_{3}$ to $\mathrm{Al}_{2} \mathrm{O}_{3}$ ratios varied parallel to the $\mathrm{Al}-\mathrm{Cr}$ joint line in the Al-Cr-2Ti triangular plot. Chromite included in olivine in the non-poikilitic lithology also was $\mathrm{TiO}_{2}$-poor (1.07 wt $\%-3.17$ wt $\%)$, similar to those in the poikilitic lithology, yet with wider range up to $3.17 \mathrm{wt} \%$. Conversely, the interstitial grains of chromite in the non-poikilitic lithology were typically enriched in $\mathrm{TiO}_{2}(6.21 \mathrm{wt} \%-15.8 \mathrm{wt} \%)$ with a relatively constant atomic ratio of $\mathrm{Cr} / \mathrm{Al}(\sim 4.1)$, although some of the large grains were $\mathrm{TiO}_{2}$-poor $(1.14 \mathrm{wt} \%-1.18 \mathrm{wt} \%)$ in the cores (Figure 10). Chromite in contact with ilmenite showed a slight decrease of the $\mathrm{TiO}_{2}$ contents toward the latter (from $14.2 \mathrm{wt} \%-15.3 \mathrm{wt} \%$ to $10.4 \mathrm{wt} \%-12.2 \mathrm{wt} \%$ ), probably due to diffusion. The representative analyses are given in Table 2.

Ilmenite: It is relatively homogeneous in composition. Other than $\mathrm{TiO}_{2}(52.8 \mathrm{wt} \% \pm 1.1 \mathrm{wt} \%)$ and $\mathrm{FeO}(39.3 \mathrm{wt} \% \pm 0.9 \mathrm{wt} \%)$, it contained minor $\mathrm{MgO}$ (4.33 wt $\%-5.90 \mathrm{wt} \%), \mathrm{MnO}(0.77$ wt $\%-0.90 \mathrm{wt} \%)$ and $\mathrm{Cr}_{2} \mathrm{O}_{3}(0.48 \mathrm{wt} \%-1.42 \mathrm{wt} \%)$ (Table 2).

\section{Discussion}

\subsection{Similarity with other lherzolitic shergottites}

Y984028 shows similar petrography and mineral chemistry with other lherzolitic shergottites, especially with GRV99027. All of these shergottites have two different lithologiespoikilitic and non-poikilitic. The poikilitic lithology consists of olivine chadacrysts and low-Ca pyroxene oikocrysts with euhedral chromite inclusions in the silicates. The nonpoikilitic lithology contains euhedral or subeuhedral olivine, low-Ca pyroxene and Ca-pyroxene with interstitial plagioclase, merrilite, apatite, ilmenite, Ti-rich chromite, pyrrhotite and accessory baddeleyite. In addition, the mineral chemistry shows distinct compositions with the textural occurrences, with lower $\mathrm{FeO}$ in olivine and pyroxene, lower $\mathrm{TiO}_{2}$ in chromite in the poikilitic lithology than in the non-poikilitic lithology.

Modal compositions of lherzolitic shergottites show significant variation (Table 1), partially due to heterogeneous sampling. This is especially the case for plagioclase glass, which is confined to non-poikilitic lithology. However, the plagioclase-depletion of Y984028 and GRV 99027 may be inherent, as indicated by their similar low abundances of plagioclase glass in the non-poikilitic lithology (Table 1). Although plagioclase glass was rare in the poikilitic lithology, the abundances of plagioclase glass in bulk ALHA77005 and LEW 88516 were compatible to those of the non-poikilitic lithology of Y984028 and GRV 99027 (Table 1). It also is noted that the poikilitic lithology of Y984028 contains much higher pyroxene (58.3 vol\%) relative to olivine (39.6 vol\%), similar to GRV 99027 (67.8 vol\% vs. 30.9 vol\%). Conversely, both ALHA77005 and LEW 88516 are olivine-rich (Table 1).

The mineral chemistry of Y984028 is nearly identical to that of GRV 99027. The Fa contents of olivine in Y984028 show a bimodal pattern with the peaks at $\mathrm{Fa}_{27}$ and $\mathrm{Fa}_{30-31}$, overlapping with GRV 99027 (Figure 6). Moreover, the compositions of pyroxenes in Y984028 also plot within the ranges of GRV 99027 (Figures 7 and 8). The similarity of Y984028 to GRV 99027 is further confirmed by the compositions of chromite (Figure 10). A significant difference between Y984028 and GRV 99027 is that there was a wider range of plagioclase glass compositions $\left(\mathrm{An}_{23-55}\right)$ in the former than in the latter $\left(\mathrm{An}_{42-61}\right)$ (Figure 9).

Regardless of the similar petrography and mineral chemistry characteristics of Y984028 and GRV 99027, this new lherzolitic shergottite is not paired with the latter. As described above, Y984028 shows the unique shock-induced microtextures of the melt veins (i.e. flow features of clear plagioclase glass with schlieren ferromagnesian silicates, abundant small mineral fragments and granulated olivine 
and chromite), distinguished from GRV 99027 and other lherzolitic shergottites. It is possible that Y984028 was ejected from the same igneous unit on Mars as other lherzolitic shergottites by a single impact event, but this meteorite experienced a distinct post-shock thermal history. Alternatively, Y984028 may have been derived from a different site on Mars by another shock event. In any case, further study of the cosmic ray exposure history of Y984028 is required in order to test these possibilities.

\subsection{Quenching at ambient pressure after shock}

Similar to other lherzolitic shergottites, Y984028 was severely shocked, producing the network of melt veins and transforming plagioclase to glass. The complete extinction of plagioclase glass in the host rock under cross-polarized light indicates that Y984028 suffered little thermal metamorphism after the main impact event. This is confirmed by the presence of clear glass in the impact melt veins. Comparatively, GRV 99027 was significantly modified by postimpact thermal metamorphism, as indicated by a high degree of recrystallization of plagioclase glass and impact melt pockets [13]. Partial recrystallization of plagioclase glass also was reported in ALHA77005 [2,4]. In addition, the impact melt pockets in ALHA77005 also were crystallized [24].

As described above, the melt veins of Y984028 are characterized by abundant small fragments of minerals, flow features of plagioclase glass with schlieren of ferromagnesian silicates, absence of any high-pressure polymorphs, and prevalent granulation textures of olivine and chromite. The absence of ringwoodite, majorite, or other high pressure polymorphs in the melt veins cannot be due to retrograde metamorphism because Y984028 experienced little thermal metamorphism after the main impact event, as discussed above. These observations indicate that Y984028 was partially melted by a shock event and then quenched at ambient pressure after decompression. If the melt veins were quenched at high pressure, majorite-pyrobe and ringwoodite would have crystallized from the melt veins in Y984028, as those reported in ordinary chondrites [23].

The presence of abundant small mineral silicates in the melt veins suggest that the shock-induced maximum temperature (or heat energy) of Y984028 was not very high. Hence, the degree of partial melting was low, with abundant small mineral fragments remaining. This is different from the typical melt veins in heavily shocked ordinary chondrites, which usually retain large rounded host rock clasts. It is possible that Y984028 was adiabatically melted as the shock-induced high pressure was released. This is consistent with the low degree of partial melting of the veins, and the consequent quench at ambient pressure. In the melt veins of Y984028, it is also noted that most plagioclase was melted, followed by a portion of pyroxene. Conversely, olivine mainly remained as fragments, which is consistent with the higher melting temperatures compared to plagioclase $(\sim 1300$ $\left.-1400^{\circ} \mathrm{C}\right)$, and low-Ca pyroxene $\left(\sim 1500^{\circ} \mathrm{C}\right)$ compared to olivine $\left(1900^{\circ} \mathrm{C}\right)$ at ambient pressure.

The granulation textures of olivine and chromite indicate incipient melting. The textures also suggest that the temperature probably was close to the melting point of olivine (i.e. $\sim 1900^{\circ} \mathrm{C}$ at ambient pressure. This temperature also is within the melting temperature range of chromite, $(\sim 1850$ $2200^{\circ} \mathrm{C}$ ) at ambient pressure. The shock-induced melt had higher $\mathrm{Mg}^{\#}$ than the bulk meteorite, because more pyroxene $\left(\mathrm{Fs}_{15-27}\right)$ was melted in comparison with olivine $\left(\mathrm{Fa}_{29.6-33.5}\right)$. In the cooling stage, olivine may have begun to crystallize from the melt, and thus was Fe-poor compared to the relict cores. As olivine grew, probably accompanying oxidization of metal and sulfides in the melt veins, the $\mathrm{Mg}^{\#}$ of the melt decreased, and the subsequently formed olivine rims were Fa-rich, producing rhythmic concentric zoning of euhedral olivine grains.

Another scenario is that Y984028 was severely shocked to form the melt vein in the same manner as other heavily shocked ordinary chondrites, but experienced a distinct post-shock temperature-pressure path with faster release of pressure than decrease of temperature, which never approached the ringwoodite-majorite region. However, this model would be expected to show evidence of intense melting of the veins, which is inconsistent with the presence of abundant small mineral fragments, which may suggest a low degree of melting. Furthermore, this scenario is not consistent with the absence of high-pressure polymorphs in the melt veinlets (10 $\mu \mathrm{m}$ wide) which should be quenched very fast before decompression.

All grains of plagioclase in the host of Y984028 were transformed to glass during the impact event. However, contrary to the recent discovery of evidence for plagioclase liquid quenching to glass at high-pressure [25], meandering mineral schlieren were not found in most plagioclase grains in Y984028. Neither fragments of olivine nor pyroxene near the plagioclase interface show whirl drift into plagioclase nor their partial melting to streaky schlieren in the host rock of Y984028. Conversely, coexisting plagioclase grains with various brightness in the BSE images maintained straight boundaries and sharp contrast (Figure 2(a) and (b)), which are indicative of non-molten conditions. This also is confirmed by EPMA profiles across boundaries of plagioclase grains, which reveal no gradual zonation. The observations of plagioclase in Y984028 suggest that it is diaplectic glass.

\section{Conclusions}

Y984028 is very similar to GRV 99027 in petrography and mineral chemistry, including low abundance of plagioclase, high abundance of pyroxene relative to olivine in the poikilitic lithology, distribution pattern of Fa-contents of olivine, and chemical compositions of pyroxenes and chromite. 
However, Y984028 is not paired with GRV 99027 or other lherzolitic shergottites based on its shock features.

Y984028 was severely shocked, producing melt veins and transforming plagioclase to glass. The complete extinction of plagioclase glass under cross-polarized light and preservation of clear glass in the melt veins suggest that Y984028 suffered from no significant thermal metamorphism after the main impact event. The melt veins of Y984028 are characterized by the absence of high-pressure polymorphs, presence of abundant minute mineral fragments, and prevalent granulated olivine and chromite grains. These observations indicate adiabatic melting during release of shock-induced high-pressure, followed by quenching at ambient pressure. The straight boundaries of individual grains of plagioclase in the host rock and absence of compositional zoning between them suggest that the plagioclase glass in the host rock was not melted, but produced by solid-solid transformation.

The authors are grateful to the reviewers, A. El Goresy and Q. Yin, and the editor, Y. Niu, for their constructive reviews, which significantly improved the manuscript. The sample was supplied by the National Institute of Polar Research, Japan. This work was supported by the Knowledge Innovation Program of the Chinese Academy of Sciences (KZCX2-YW-110 and KZCX2-YW-Q08).

1 Harvey R P, Wadhwa M, McSween Jr H Y, et al. Petrography, mineral chemistry, and petrogenesis of Antarctic shergottite LEW88516. Geochim Cosmochim Acta, 1993, 57: 4769-4783

2 Ikeda Y. Petrography and petrology of the ALH-77005 shergottite. Antarct Meteorite Res, 1994, 7: 9-29

3 Ikeda Y. Petrology and mineralogy of the Y-793605 Martian meteorite. Antarct Meteorite Res, 1997, 10: 13-40

4 Treiman A H, McKay G A, Bogard D D, et al. Comparison of the LEW88516 and ALHA77005 Martian meteorites: Similar but distinct. Meteoritics, 1994, 29: 581-592

5 Gleason J D, Kring D A, Hill D H, et al. Petrography and bulk chemistry of Martian lherzolite LEW88516. Geochim Cosmochim Acta, 1997, 61: 4007-4014

6 Mikouchi T, Miyamoto M. Yamato-793605: A new lherzolitic shergottite from the Japanese Antarctic meteorite collection. Antarct Meteorite Res, 1997, 10: 41-60

7 Borg L E, Nyquist L E, Wiesmann H, et al. Constraints on the petrogenesis of Martian meteorites from the $\mathrm{Rb}-\mathrm{Sr}$ and $\mathrm{Sm}-\mathrm{Nd}$ isotopic systematics of the lherzolitic shergottites ALH77005 and LEW88516. Geochim Cosmochim Acta, 2002, 66: 2037-2053
8 Morikawa N, Misawa K, Kondorosi G, et al. Rb-Sr isotopic systematics of lherzolitic shergottite Yamato-793605. Antarct Meteorite Res, 2001, 14: 47-60

9 Eugster O, Polnau E. Mars-Earth transfer time of lherzolite Yamato-793605. Antarct Meteorite Res, 1997, 10: 143-149

10 Eugster O, Weigel A, Polnau E. Ejection times of Martian meteorites. Geochim Cosmochim Acta, 1997, 61: 2749-2757

11 Kong P, Fabel D, Brown R, et al. Cosmic-ray exposure age of Martian meteorite GRV 99027. Sci China Ser D-Earth Sci, 2007, 50: 1521-1524

12 Lin Y T, Wang D D, Miao B K, et al. Grove Mountains (GRV) 99027: A new Martian meteorite. Chinese Sci Bull, 2003, 48: 1771-1774

13 Lin Y T, Guan Y B, Wang D D, et al. Petrogenesis of the new lherzolitic shergottite Grove Mountains 99027: Constraints of petrography, mineral chemistry, and rare earth elements. Meteorit Planet Sci, 2005, 40: 1599-1619

14 Lin Y T, Qi L, Wang G Q, et al. Bulk chemical composition of lherzolitic shergottite Grove Mountains 99027-Constraints on the mantle of Mars. Meteorit Planet Sci, 2008, 43: 1179-1187

15 Hsu W B, Guan Y B, Wang H N, et al. The lherzolitic shergottite Grove Mountains 99027: Rare earth element geochemistry. Meteorit Planet Sci, 2004, 39: 701-709

16 Mikouchi T, Kurihara T. Mineralogy and petrology of paired lherzolitic shergottites Yamato 000027, Yamato 000047, and Yamato 000097: Another fragment from a Martian "lherzolite" block. Polar Sci, 2008, 2: 175-194

17 Gillet P, Barrat J A, Beck P, et al. Petrology, geochemistry, and cosmic-ray exposure age of lherzolitic shergottite Northwest Africa 1950. Meteorit Planet Sci, 2005, 40: 1175-1184

18 Miao B, Ouyang Z, Wang D, et al. A new Martian meteorite from Antarctica: Grove Mountains (GRV) 020090. Acta Geol Sin, 2004, 78: 1034-1041

19 Mikouchi T, Kurihara T, Miyamoto M. Petrology and mineralogy of RBT 04262: Implications for stratigraphy of the lherzolitic shergottite igneous block. In: LPS XXXIX. 2008. 2403

20 Usui T, Sanborn M E, Wadhwa M, et al. Petrogenesis of geochemically enriched lherzolitic shergottites RBT 04261 and RBT 04262. In: 71st Annual Meteoritical Society Meeting. Matsue, 2008, 43(Suppl): 5052

$21 \mathrm{Hu} \mathrm{S}$, Feng L, Lin Y T. Petrology and mineral chemistry of the Y984028 lherzolitic shergottite. In: Antarct Meteorit Symp XXXII. 2009. 22-23

22 Delaney J S. Petrological comparison of LEW 88516 and ALHA 77005 shergottites. Meteoritics, 1992, 27: 213-214

23 Chen M, Sharp T, El Goresy A, et al. The majorite-pyrope + magnesiowustite assemblage: Constraints on the history of shock veins in chondrites. Science, 1996, 271: 1570-1573

24 Walton E L, Herd C D K. Dynamic crystallization of shock melts in Allan Hills 77005: Implications for melt pocket formation in Martian meteorites. Geochim Cosmochim Acta, 2007, 71: 5267-5285

25 El Goresy A, Miyahara M, Ozawa S, et al. Liquidus high-pressure assemblages in shocked martian shergottites: Constraints to equilibrium peak shock-pressures and consequences to radiometric ages. In: 73rd Annual Meteoritical Society Meeting, New York, 2010. 5020

Open Access This article is distributed under the terms of the Creative Commons Attribution License which permits any use, distribution, and reproduction in any medium, provided the original author(s) and source are credited. 